Turk J Biod, March 2019, 2(1): 13-17

Journal homepage: http://turkbiod.artvin.edu.tr/

http://dergipark.gov.tr/biodiversity

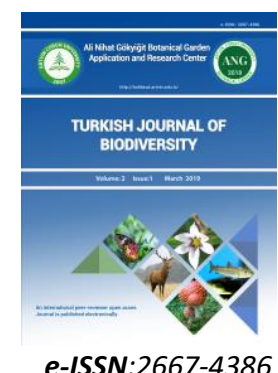

\title{
Evaluation of antioxidant capacity with total phenolic content of Galanthus krasnovii (Amaryllidaceae)
}

\author{
Galanthus krasnovii (Amaryllidaceae)'nin toplam fenolik içeriği ile antioksidan kapasitenin değerlendirilmesi

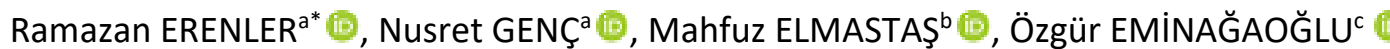 \\ a Plant Research Laboratory, Department of Chemistry, Faculty of Arts and Sciences, Tokat Gaziosmanpasa University, Tokat, Turkey \\ ${ }^{b}$ Department of Biochemistry, Faculty of Pharmacy, University of Health Sciences, Istanbul, Turkey \\ c Department of Forest Engineering, Faculty of Forestry, Artvin Coruh University, Artvin, Turkey
}

\begin{abstract}
Article Info
(C)2018 Ali Nihat Gökyiğit Botanical Garden Application and Research Center of Artvin Coruh University.

*Corresponding author:

e-mail: ramazan.erenler@gop.edu.tr ORCID: 0000-0002-0505-3190

\section{Article history}

Received: February 13, 2019

Received in revised form: March 12, 2019

Accepted: March 13, 2019

Available online: March 15, 2019
\end{abstract}

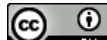

This is an Open Access article under the CC BY license (http://creativecommons.org/licenses /by/4.0/).

\section{Keywords: \\ Galanthus krasnovii, antioxidant, natural product, phenolic contents.}

Anahtar kelimeler:

Galanthus krasnovii, antioksidan, doğal ürün, fenolik içerik.

\begin{abstract}
Natural products have gained the great interest due to their broad spectrum of biological activities. Galanthus krasnovii was dried at shade then extracted with hexane, dichloromethane, and ethyl acetate successively. After removing of solvent by reduced pressure, crude extracts of each solvent were yielded. Antioxidant activity including 1,1-diphenyl-2-picrylhydrazyl (DPPH) radical, 2,2'-azinobis(3-ethylbenzothiazoline-6-sulphonic acid) (ABTS) radical cation and reducing power assays were carried out for each extract. Moreover, total phenolic content was determined. Total phenolic content of hexane-, dichloromethane-, and ethyl acetate extracts were found as $60.95 \mathrm{mg} \mathrm{GAE} / \mathrm{g}$ extract, 71.90 $\mathrm{GAE} / \mathrm{g}$ extract and $58.90 \mathrm{GAE} / \mathrm{g}$ extract respectively. Dichloromethane and ethyl acetate extract revealed the moderate antioxidant activity.
\end{abstract}

\section{öz}

Doğal ürünler geniş spektrumlu biyolojik aktivite göstermelerinden dolayı yoğun ilgi görmektedirler. Galanthus krasnovii gölgede kurutulduktan sonra sırasıyla hekzan, diklorometan ve etil asetat ile ekstrakte edildi. Düşük basınçta çözücü uzaklaştıııldıktan sonra her bir çözücünün ekstraktı elde edildi. Her bir ekstraktın, 1,1-difenil-2- pikralhidrazil(DPPH) radikal, 2,2'-azino-bis(3- etilbenzotiazolin-6sülfirik asit) (ABTS) radikal katyon ve indirgeme gücü antioksidan çalışmaları gerçekleştirildi. Ayrıca, ekstraktların toplam fenolik içerikleri belirlendi. Hekzan-, diklorometan- ve etil asetat ekstraktlarının toplam fenolik içerikleri sırasıyla $60.95 \mathrm{mg}$ GAE/g ekstrakt, $71.90 \mathrm{GAE} / \mathrm{g}$ ekstrakt ve $58.90 \mathrm{GAE} / \mathrm{g}$ ekstrakt olarak belirlendi. Diklorometan ve etil asetat ekstraktları orta derece aktivite gösterdi.

\section{Citation:}

To cite this article: Erenler R, Genç N, Elmastaş M, Eminağaoğlu Ö (2019). Evaluation of antioxidant capacity with total phenolic content of Galanthus krasnovii (Amaryllidaceae). Turk J Biod 2(1): 13-17.

\section{INTRODUCTION}

Plants play a significant role in drug discovery process. Since they reveal plenty of pharmaceutical properties, isolation of bioactive compounds from plants gains the great interest to find the most effective compounds with activity mechanism (Aksit et al., 2014; Demirtas et al., 2013; Elmastas et al., 2016; Elmastaş et al., 2015; Erenler, Demirtas, et al., 2017; Erenler, Meral, et al., 2017; Erenler, Sen, Aksit, et al., 2016; Erenler, Sen, Yaglioglu, et al., 2016;
Erenler et al., 2018; Guzel et al., 2017; Karan et al., 2017; Karan \& Erenler 2017a; Karan \& Erenler 2018; Karan \& Erenler 2017b; Karan et al., 2018; Topçu et al., 1999; Yaglıoglu et al., 2013; Yildiz et al., 2017).

Galanthus L. genus, known as snowdrops, belonging to Amaryllidaceae family consists of 20 species distributed throughout Europe, Asia and Near East (Zubov \& Davis 2012). Six species are endemic for Turkey flora (Davis \& Özhatay, 2001). Turkey is one of the centers of species 
diversity of Galanthus. It is the most traded ornamental bulb genus in the world and a great number of bulbs are exported from Turkey each year. This genus is very popular garden plant in Europe and is especially considered as the early messenger of spring. Some of the Galanthus species have been included in the red list of threatened species (Convention on International Trade in Endangered Species of Wild Fauna and Flora - CITES) due to the extensive collection, climate change, and habitat destruction.

Previous phytochemical study on Galanthus species provided the isolation of bioactive alkaloids such as tazettine, galanthusine, molycorine, galanthamine, gananthine (Berkov et al., 2012; Kintsurashvili \& Vachnadze, 2007). Galanthus woronowii Losinsk. collected from Trabzon, Turkey included the galanthine, galanthamine, 2-O-(3'-hydroxybutanoyl) lycorine, narwedine, $O$-methylleucotamine, sternbergine, lycorine, sanguinine, salsoline (Sarikaya et al., 2013). Galanthus species have been used in homeopathy to treat various illness such as headaches, cardiac failure, mitral disorder (Bokov \& Samylina, 2016). Galanthamine, a main constituent of Galanthus species, is a licensed drug for the treatment of dementia in Alzheimer's disease. It inhibits the Acetylcholinesterase (AChE) selectively and competitively (Ellis et al., 2009).

Reactive oxygen species are free radicals yielding in human body during the oxidative function. Human body has defense mechanism against oxidative stress such as enzymes and compounds. Natural antioxidants become inadequate under some circumstance such as malnutrition, ultra violet radiation, and smoking. Hence, excess free radical is able to damage to cell membrane leading to degenerative illness and conditions such as Alzheimer's disease, cardiovascular disease, process, diabetes, inflammation and DNA injury leading to carcinogenesis. Antioxidants play an important role for inhibiting or quenching free radicals. Antioxidants have been used in food, cosmetics and medicine to replace synthetic antioxidants forbidden because of their carcinogenicity (Sasaki et al., 2002). There is not any report about the antioxidant activity of Galanthus krasnovii A.P.Khokhr.

In this work, it was presented the antioxidant potency of Galanthus krasnovii using $\mathrm{DPPH}^{\circ}, \mathrm{ABTS}^{\circ}$, and reducing power assays. In addition, total phenolic content was executed.

\section{MATERIAL AND METHOD}

\subsection{General experimental procedures}

UV analysis was carried out with Hitachi U-290 UV-VIS spectrophotometer. Potassium persulphate $\left(\mathrm{K}_{2} \mathrm{~S}_{2} \mathrm{O}_{8}\right)$, trolox, amonyum acetate $\left(\mathrm{NH}_{4} \mathrm{CO}_{2} \mathrm{CH}_{3}\right)$, butlylaed hydroxytoluene (BHT), butlylated hydroxyanisole (BHA), 2,2'-azino-bis(3-ethylbenzothiazoline-6-sulphonic acid) diammonium salt (ABTS), 1,1-diphenyl-2-picrylhydrazyl (DPPH) were supplied by Sigma (Sigma-Aldrich $\mathrm{GmbH}$, Steinheim, Germany). The solvents with analytical grade, potassium dihydrogen phosphate $\left(\mathrm{KH}_{2} \mathrm{PO}_{4}\right)$, potassium hydroxide $(\mathrm{KOH})$, cupper (II) chloride $\left(\mathrm{CuCl}_{2}\right)$, FolinCiocalteu reagent, gallic acid were bought from E. Merck (Darmstadt, Germany).

\subsection{Plant material}

The voucher specimens have been deposited at the Herbarium of Artvin Coruh University (ARTH), Artvin, Turkey. G. krasnovii was collected from Turkey: A8 Artvin, Kafkasör, 1100 m, in 05.04.2018 and identified by Prof. Dr. Özgür Eminağaoğlu, specialists of Plant Taxonomy (ARTH 13437).

\subsection{Extraction}

G. krasnovii (100 g) was extracted with hexane $(2 \times 100$ $\mathrm{mL})$, dichloromethane $(2 \times 100 \mathrm{~mL})$ and ethyl acetate $(2 \times$ $100 \mathrm{~mL}$ ) sequentially for 2 days. After removing of solvent from each extract solution under reduced pressure, the crude extracts of hexane $(1.5 \mathrm{~g})$, dichloromethane $(1.2 \mathrm{~g})$ and ethyl acetate $(1.3 \mathrm{~g})$ were yielded. The extracts were kept in fridge to analyze the antioxidant activity with total phenolic content (Genç et al., 2019).

\subsection{Total phenolic determination}

Total phenolic compounds of $G$. krasnovii extracts (hexane, dichloromethane and ethyl acetate) was executed by Folin-Ciocalteu method (Singleton \& Slinkard 1977). The extract solution $(1.0 \mathrm{mg} / 1 \mathrm{~mL})$ was reacted with Folin ciocalteu $(0.1 \mathrm{~mL})$ in distillated water $(4.6 \mathrm{~mL})$. After addition of sodium carbonate solution $(0.3 \mathrm{~mL}, 2 \%)$, the reaction mixture was incubated for $2 \mathrm{~h}$ at room temperature. The absorbance was determined at $765 \mathrm{~nm}$ by a spectrophotometer. The standard curve was calculated using gallic acid and the results were presented 
as gallic acid equivalents per mg of extract (Erenler et al., 2014). All experiments were carried out in triplicate.

\subsection{DPPH free radical scavenging assay}

$\mathrm{DPPH}^{\bullet}$ activity of hexane-, dichloromethane- and ethyl acetate extracts of $G$. krasnovii was carried out by the protocol reported (Blois 1958). DPPH• $(1.0 \mathrm{~mL}, 0.26 \mathrm{mM})$ was reacted with various concentration of each extract solution $(3.0 \mathrm{~mL})$ for $15 \mathrm{~min}$ at $\mathrm{rt}$. Tha absorbance was determined at $517 \mathrm{~nm}$. BHA, BHT and Trolox were used as standard controls. $I C_{50}$ values indicate the concentration of sample that scavenges $50 \%$ of DPPH free radical. The $\mathrm{DPPH}^{\circ}$ scavenging activity was calculated using the equation:

$\mathrm{DPPH}^{\bullet}$ scavenging effect $(\%)=\left[\left(\mathrm{A}_{1}-\mathrm{A}_{2}\right) / \mathrm{A}_{1}\right] \times 100$

$A_{1}$ is the absorbance of the control and $A_{2}$ is the absorbance of the sample (Elmastas et al. 2004).

\subsection{ABTS radical cation scavenging assay}

$A B T S$ radical cation activity was executed by the protocol reported previously (Re et al. 1999). Initially, ABTS ${ }^{*+}$ stock solution was prepared by the treatment of ABTS ( $2 \mathrm{mM}$ ) with potassium persulfate $(2.45 \mathrm{mM})$. Later, it was kept for $6 \mathrm{~h}$ in dark at rt. Each extract solution $(3.0 \mathrm{~mL})$ was reacted with $\mathrm{ABTS}^{\circ+}$ solution $(1.0 \mathrm{~mL})$. The absorbance was determined at $734 \mathrm{~nm}$ by a spectrophotometer. The inhibition was calculated for each concentration in comparison to a blank absorbance (Erenler et al. 2015). ABTS $^{*+}$ activity was calculated by the equation: $\mathrm{ABTS}^{*+}$ scavenging effect $(\%)=\left[\left(A_{1}-A_{2}\right) / A_{1}\right] \times 100$ in which, $A_{1}$ is $A B T S^{*+}$ initial concentration and $A_{2}$ is $A B T S^{\circ+}$ remaining concentration in the sample. The results were calculated as $\mathrm{IC}_{50}$.

\subsection{Cupric ion reducing power assay}

Cupric ion reducing power assay was carried out for each extract of G. krasnovii (Elmastas et al., 2018). The reduction capacity of each extract can be calculated by the efficient reduction of $\mathrm{Cu}^{+2}$ to $\mathrm{Cu}^{+1}$. The yellow complex formed after addition of cupper (I) chloride. The extract $(40-160 \mu \mathrm{g} / \mathrm{mL}, 1.0 \mathrm{~mL}), \mathrm{CuCl}_{2}(0.01 \mathrm{M}, 1.0 \mathrm{~mL})$, neocuproine $\left(1.0 \mathrm{~mL}, 7.5 \times 10^{-3} \mathrm{M}\right)$, and acetate tampon $(1.0 \mathrm{~mL}, 1.0 \mathrm{M})$ were added to the reaction flask and incubated for $30 \mathrm{~min}$. The absorbance was recorded at $450 \mathrm{~nm}$ (Apak et al., 2004). The result was expressed according to the Trolox equivalent ( $\mu \mathrm{mol} / \mathrm{g}$ sample).

\section{RESULTS AND DISCUSSION}

Galanthus species are significant plants including the bioactive compound used in drug. Some species of Galanthus genus were reported to reveal the antioxidant activity. Antioxidant activity of various parts (root, leaf, flower and bulb) of Galanthus elwesii Hook.f. was executed at different growing stages such as beginning, flowering, after flowering and fruit ripening. The part of the plant and growing stage altered the activity significantly. The leaf at fruit ripening stage of G. elwesii displayed the most antioxidant activity (Ay et al., 2018). G. transcaucasicus Fomin shoot extract revealed the considerable antioxidant and antimicrobial activity (Karimi et al., 2018). In this study, hexane-, dichloromethane- and ethyl acetate extracts of Galanthus krasnovii were investigated for antioxidant activity as well as total phenolic content. Total phenolic content of hexane, dichloromethane and ethyl acetate extracts was found as $60.95 \mathrm{mg} \mathrm{GAE} / \mathrm{g}$ extract, $71.90 \mathrm{GAE} / \mathrm{g}$ extract and $58.90 \mathrm{GAE} / \mathrm{g}$ extract respectively. Hexane extract did not reveal the DPPH free radical activity. However, dichloromethane extract and EtOAc extract exhibited the moderate activity (Figure 1).

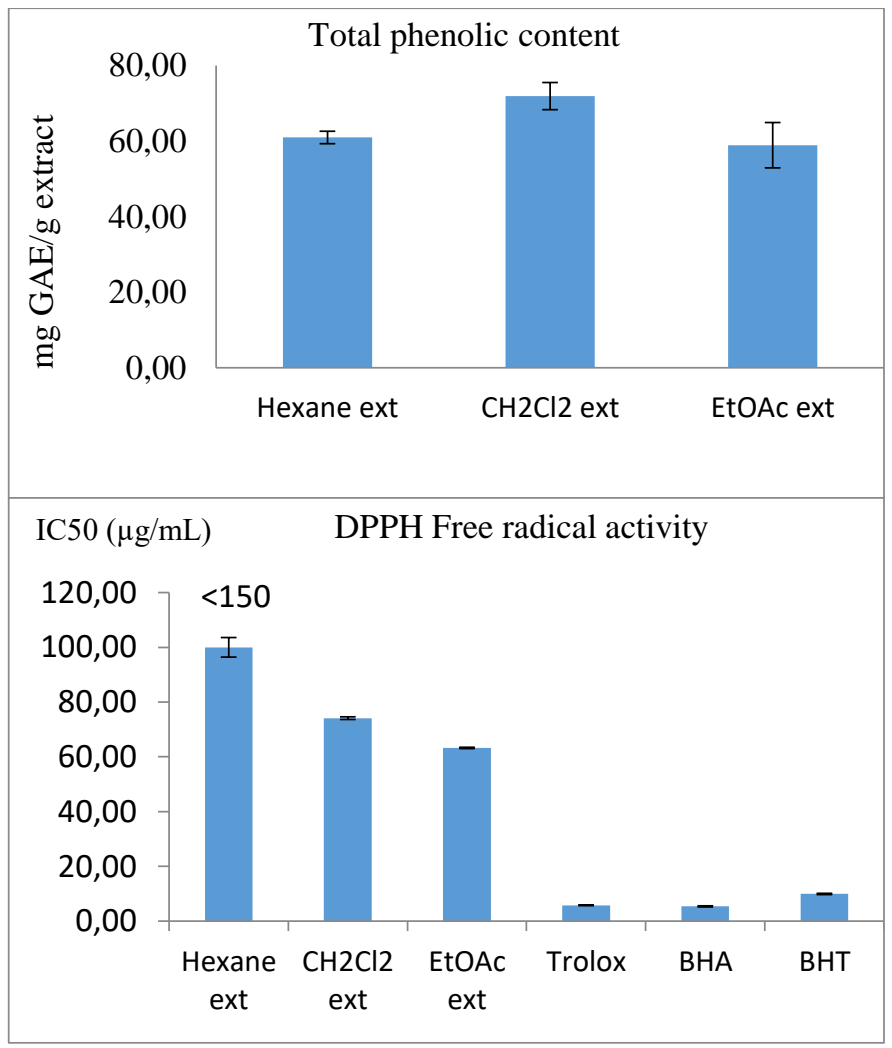

Figure 1. Total phenolic content and DPPH free radical activity 
In regarding $A B T S$ radical cation activity, dichloromethane extract and EtOAc extract displayed the mild activity with $14.33\left(\mathrm{IC}_{50}, \mu \mathrm{g} / \mathrm{mL}\right)$ and $14.98\left(\mathrm{IC} \mathrm{C}_{50}, \mu \mathrm{g} / \mathrm{mL}\right)$ respectively compared to the standard BHA $\left(8.8, \quad \mathrm{IC}_{50}, \mu \mathrm{g} / \mathrm{mL}\right)$. Reducing power activity was executed with respect to trolox equivalent. Dichloromethane extract $(1.15 \mu \mathrm{mol} \mathrm{TE}$ / mg extract) displayed the most reducing power effect among the extracts tested. Ethyl acetate and hexane extracts revealed the activity of $0.77 \mu \mathrm{mol} \mathrm{TE} / \mathrm{mg}$ extract and $0.75 \mu \mathrm{mol}$ TE / mg extract, respectively. This result revealed that the compounds in dichloromethane extract had electron donation ability to reduce from $\mathrm{Cu}^{+2}$ to $\mathrm{Cu}^{+1}$.
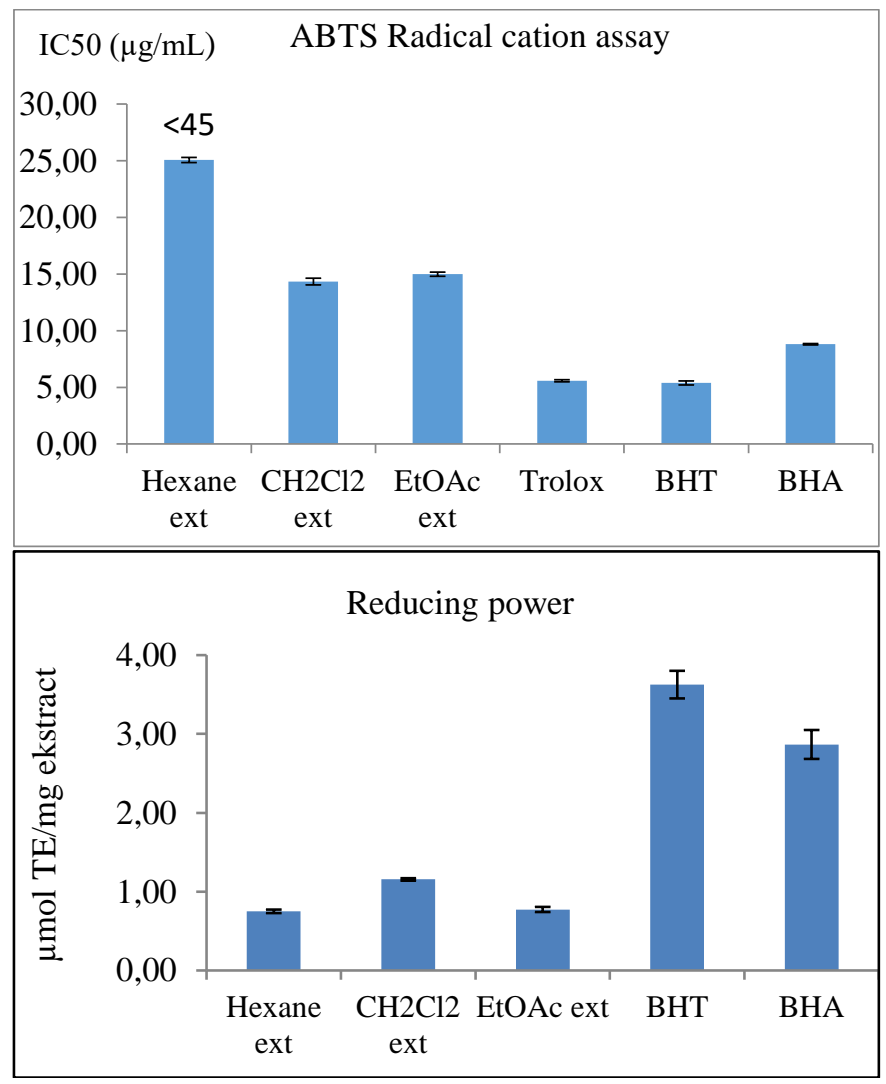

Figure 2. ABTS Radical cation assay and reducing power

\section{CONCLUSIONS}

G. krasnovii has a potency to be used in pharmaceutical and food industry as a natural antioxidant. The cultivation area of $G$. krasnovii should be enlarged. Bioactive compounds should be isolated and alkaloids quantity of G. krasnovii should be increased by using various agricultural techniques. Antioxidant effects of isolated compounds should be investigated and activity-structure mechanism should be presented.

\section{REFERENCES}

Aksit H, Çelik SM, Sen Ö, Erenler R, Demirtas I, Telci I, Elmastas M (2014). Complete isolation and characterization of polar portion of Mentha dumetorum water extract. Records of Natural Products 8:277-280.

Apak R, Güçlü K, Özyürek M, Karademir SE (2004). Novel total antioxidant capacity index for dietary polyphenols and vitamins $C$ and $\mathrm{E}$, using their cupric ion reducing capability in the presence of neocuproine: CUPRAC method. Journal of Agricultural and Food Chemistry 52: 7970-7981.

Ay EB, Gül M, Açikgöz MA, Yarilgaç T, Kara ŞM (2018). Assessment of antioxidant activity of giant snowdrop (Galanthus elwesii Hook) extracts with their total phenol and flavonoid contents. Indian Journal of Pharmaceutical Education and Research 52: 128-132.

Berkov S, Codina C, Bastida J (2012). The genus Galanthus: A source of bioactive compounds. In: Phytochemicals-A Global Perspective of Their Role in Nutrition and Health. IntechOpen, 235-254.

Blois MS (1958). Antioxidant determinations by the use of a stable free radical. Nature 181: 1199-1200.

Bokov D, Samylina I (2016). Identification of Flavonoids in Homeopathic Mother Tinctures of Galanthus woronowii Losinsk. And Galanthus nivalis L. by Ultra-Performance Liquid Chromatography with Photodiode Arrays and Tandem Quadrupole Mass-Selective Detectors. Pharmaceutical Chemistry Journal 50: 458-464.

Davis AP, Özhatay N (2001). Galanthus trojanus: a new species of Galanthus (Amaryllidaceae) from north-western Turkey. Botanical Journal of the Linnean Society 137: 409-412.

Demirtas I, Erenler R, Elmastas M, Goktasoglu A (2013). Studies on the antioxidant potential of flavones of Allium vineale isolated from its water-soluble fraction. Food Chemistry 136: 34-40.

Ellis J, Nathan P, Villemagne V, Mulligan R, Saunder T, Young K, Smith C, Welch J, Woodward M, Wesnes K (2009). Galantamine-induced improvements in cognitive function are not related to alterations

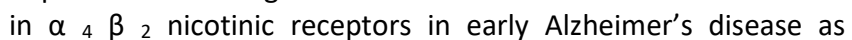
measured in vivo by 2-[18 ${ }^{18}$ F] Fluoro-A-85380 PET. Psychopharmacology 202: 79-91.

Elmastas M, Celik SM, Genc N, Aksit H, Erenler R, Gulcin I (2018). Antioxidant activity of an Anatolian herbal tea-Origanum minutiflorum: isolation and characterization of its secondary metabolites. International Journal of Food Properties 21: 374-384.

Elmastas M, Erenler R, Isnac B, Aksit H, Sen O, Genc N, Demirtas I (2016). Isolation and identification of a new neo-clerodane diterpenoid from Teucrium chamaedrys L. Natural Product Research 30: 299-304.

Elmastas M, Ozturk L, Gokce I, Erenler R, Aboul-Enein HY (2004). Determination of antioxidant activity of marshmallow flower (Althaea officinalis L.). Analytical Letters 37: 1859-1869.

Elmastaş M, Telci I, Akşit H, Erenler R (2015). Comparison of total phenolic contents and antioxidant capacities in mint genotypes used as spices/Baharat olarak kullanılan nane genotiplerinin toplam fenolik içerikleri ve antioksidan kapasitelerinin karşılaştırılması. Turkish Journal of Biochemistry 40: 456-462.

Erenler R, Demirtas I, Karan T, Altun M, Gul F (2017). Inhibitory Effect of 6, 7-dimethoxy-5-hydroxyflavone on Human Cervix Carcinoma in Vitro. International Journal of Secondary Metabolite 4: 512-516.

Erenler R, Meral B, Sen O, Elmastas M, Aydin A, Eminagaoglu O, Topcu $G$ (2017). Bioassay-guided isolation, identification of compounds from Origanum rotundifolium and investigation of their 
antiproliferative and antioxidant activities. Pharmaceutical Biology 55: 1646-1653.

Erenler R, Sen O, Aksit H, Demirtas I, Yaglioglu AS, Elmastas M, Telci i (2016). Isolation and identification of chemical constituents from Origanum majorana and investigation of antiproliferative and antioxidant activities. Journal of the Science of Food and Agriculture 96: 822-836.

Erenler R, Sen O, Yaglioglu AS, Demirtas I (2016). Bioactivity-guided isolation of antiproliferative sesquiterpene lactones from Centaurea solstitialis L. ssp. solstitialis. Combinatorial Chemistry \& High Throughput Screening 19: 66-72.

Erenler R, Telci I, Elmastaş M, Akşit H, Gül F, Tüfekçi AR, Demirtaş I, Kayir Ö (2018). Quantification of flavonoids isolated from Mentha spicata in selected clones of Turkish mint landraces. Turkish Journal of Chemistry 42: 1695-1705.

Erenler R, Telci I, Ulutas M, Demirtas I, Gul F, Elmastas M, Kayir O (2015). Chemical Constituents, Quantitative Analysis and Antioxidant Activities of Echinacea purpurea (L.) Moench and Echinacea pallida (Nutt.) Nutt. Journal of Food Biochemistry 39: 622-630.

Erenler R, Yilmaz S, Aksit H, Sen O, Genc N, Elmastas M, Demirtas I (2014). Antioxidant activities of chemical constituents isolated from Echinops orientalis Trauv. Records of Natural Products 8(1): 32-36.

Genç N, Yıldız I, Karan T, Eminağaoğlu Ö, Erenler R (2019). Antioxidant activity and total phenolic contents of Galanthus woronowii (Amaryllidaceae). Turkish Journal of Biodiversity 2(1): 1-5.

Guzel A, Aksit H, Elmastas M, Erenler R (2017). Bioassay-guided isolation and identification of antioxidant flavonoids from Cyclotrichium origanifolium (Labill.) Manden. and Scheng. Pharmacognosy Magazine 13(50): 316-320.

Karan T, Altuner Z, Erenler R (2017). Growth and Metabolite Production of Chroococcus minutus Under Different Temperature and Light Conditions. Journal of New Results in Science 6:47-52.

Karan T, Erenler R (2017a). Effect of Salt and pH Stress of Bioactive Metabolite Production in Geitlerinema carotinosum. International Journal of Secondary Metabolite 4: 16-19.

Karan T, Erenler R (2018). Fatty acid constituents and anticancer activity of Cladophora fracta (OF Müller ex Vahl) Kützing. Tropical Journal of Pharmaceutical Research 17: 1977-1982.

Karan T, Erenler R (2017b). Screening of norharmane from seven cyanobacteria by high-performance liquid chromatography. Pharmacognosy Magazine 13: 723-725.
Karan T, Yildiz I, Aydin A, Erenler R (2018). Inhibition of various cancer cells proliferation of bornyl acetate and essential oil from Inula graveolens (Linnaeus) Desf. Records of Natural Products 12: 273283.

Karimi E, Mehrabanjoubani P, Homayouni-Tabrizi M, Abdolzadeh A, Soltani M (2018). Phytochemical evaluation, antioxidant properties and antibacterial activity of Iranian medicinal herb Galanthus transcaucasicus Fomin. Journal of Food Measurement and Characterization 12: 433-440.

Kintsurashvili L, Vachnadze V (2007). Plants of the Amaryllidaceae family grown and introduced in Georgia: a source of galanthamine. Pharmaceutical Chemistry Journal 41: 492-494.

Re R, Pellegrini N, Proteggente A, Pannala A, Yang M, Rice-Evans C (1999). Antioxidant activity applying an improved ABTS radical cation decolorization assay. Free Radical Biology and Medicine 26: 1231-1237.

Sarikaya BB, Kaya GI, Onur MA, Bastida J, Somer NU (2013). Phytochemical investigation of Galanthus woronowii. Biochemical Systematics and Ecology 51: 276-279.

Sasaki YF, Kawaguchi S, Kamaya A, Ohshita M, Kabasawa K, Iwama K, Taniguchi K, Tsuda S (2002). The comet assay with 8 mouse organs: results with 39 currently used food additives. Mutation Research/Genetic Toxicology and Environmental Mutagenesis 519: 103-119.

Singleton VL, Slinkard K (1977). Total phenol analysis: Automation and comparison with manual methods. American Journal of Enology and Viticulture 28: 49-55.

Topçu G, Erenler R, Çakmak O, Johansson CB, Çelik C, Chai H-B, Pezzuto JM (1999). Diterpenes from the berries of Juniperus excelsa. Phytochemistry 50: 1195-1199.

Yaglıoglu AS, Akdulum B, Erenler R, Demirtas I, Telci I, Tekin S (2013). Antiproliferative activity of pentadeca-(8E, 13Z) dien-11-yn-2-one and (E)-1, 8-pentadecadiene from Echinacea pallida (Nutt.) Nutt. roots. Medicinal Chemistry Research 22: 2946-2953.

Yildiz I, Sen O, Erenler R, Demirtas I, Behcet L (2017). Bioactivityguided isolation of flavonoids from Cynanchum acutum L. subsp. sibiricum (willd.) Rech. f. and investigation of their antiproliferative activity. Natural Product Research 31: 2629-2633.

Zubov DA, Davis AP (2012). Galanthus panjutinii sp. nov.: A new name for an invalidly published species of Galanthus (Amaryllidaceae) from the northern Colchis area of Western Transcaucasia. Phytotaxa 50: 55-63. 